\title{
KARAKTERISTIK NILAI KALOR BRIKET CAMPURAN TEBU TIBARAU DAN KULIT DURIAN
}

\author{
Hendri Nurdin ${ }^{1 *}$, Hasanuddin ${ }^{1}$, Waskito ${ }^{1}$, Darmawi $^{1}$ \\ ${ }^{1}$ Jurusan Teknik Mesin, Fakultas Teknik, Universitas Negeri Padang \\ *Corresponding author, e-mail: hens2tm@yahoo.com
}

\begin{abstract}
Abstrak - Kebutuhan energi yang meningkat di masyarakat, dapat berdampak terhadap kelangkaan minyak sehingga menjadi ketergantungan terhadap energi. Pengembangan diversifikasi produk berupa briket campuran tebu tibarau dan kulit durian sebagai upaya dalam mendapatkan bahan bakar alternatif. Briket campuran tebu tibarau dan kulit durian berpotensi dijadikan sebagai sumber energi terbarukan. Upaya dan inovasi menjadikan briket campuran tebu tibarau dan kulit durian sebagai bahan bakar alternatif yang memiliki karakteristik dengan kualitas dan performa nilai kalornya. Ujicoba dan evaluasi terhadap briket campuran tebu tibarau dan kulit durian diperlukan sebelum dikembangkan dan direkomendasi sebagai bahan bakar alternatif. Melalui teknologi proses pembuatan briket dengan kompaksi dan optimalisasi kandungan komposisi dan penggunaan jenis perekat sehingga diperoleh kualitas nilai kalor yang maksimal. Dari penelitian ini diperoleh briket campuran tebu tibarau dan kulit durian yang direkomendasikan sebagai bahan bakar alternatif. Karakteristik nilai kalor briket campuran tebu tibarau dan kulit durian dengan perekat gambir diperoleh sebesar $16967,91 \mathrm{~kJ} / \mathrm{Kg}$ dengan massa jenisnya $682,23 \mathrm{Kg} / \mathrm{m}^{3}$. Briket (biomassa) yang memiliki massa jenis (densitas) yang tinggi memiliki nilai kalor yang tinggi pula. Perbandingan komposisi campuran pada pembuatan briket yaitu 40\%: $40 \%: 20 \%$. Pada pembuatan briket, konsentrasi penggunaan perekat berpengaruh terhadap nilai kalor yang dihasilkannya. Selain itu, besaran butir (mesh), gaya penekanan (kompaksi) juga mempengaruhi karakteristik nilai kalor dan massa jenis briket tersebut.
\end{abstract}

Kata Kunci : Briket, Tibarau, Kulit durian, Karakteristik, Nilai kalor

\begin{abstract}
Increased energy needs in the community, can have an impact on the scarcity of oil so that it becomes dependent on energy. The development of product diversification in the form of mixed sugar cane briquettes and durian skin in an effort to obtain alternative fuels. Briquettes mixed with sugar cane and durian skin have the potential to be used as renewable energy sources. Efforts and innovations make mixed sugar cane briquettes and durian skin as alternative fuels that have characteristics with quality and performance of the heating value. Trials and evaluations of mixed sugar cane briquettes and durian skins are needed before being developed and recommended as alternative fuels. Through the technology of the process of making briquettes with compacting and optimizing the content of the composition and use of adhesive types so that the maximum quality of the calorific value is obtained. From this study, it was obtained that mixed sugar cane briquettes and durian skins were recommended as alternative fuels. The characteristics of the heating value of mixed sugar cane briquettes and durian skin with gambir adhesives were obtained at $16967.91 \mathrm{~kJ} / \mathrm{Kg}$ with a density of $682.23 \mathrm{Kg} / \mathrm{m}^{3}$. Briquettes that have a high density have a high calorific value. Comparison of the composition of the mixture in making briquettes is $40 \%: 40 \%: 20 \%$. In the manufactured of briquettes, the concentration of the use of adhesives affects the caloric value it produces. In addition, the mesh size, force of compaction also affects the characteristics of the calorific value and density of the briquettes.
\end{abstract}

Keywords : Briquettes, Tibarau, Durian skin, Characteristic, Calorific value

This is an open access article distributed under the Creative Commons 4.0 Attribution License.

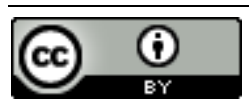




\section{Pendahuluan}

Dalam kehidupan sehari-hari masyarakat membutuhkan energi untuk berbagai kegiatannya, baik yang bersumber dari alam maupun energi hasil pengolahan diantaranya bahan bakar minyak. Seiring bertambahnya populasi manusia dan kebutuhan energi yang meningkat, dapat berdampak terhadap kelangkaan bahan bakar minyak tersebut. Dampak yang dirasakan masayarakat akibat kelangkaan maka harga bahan bakar minyak semakin meningkatnya. Lebih jauh lagi juga berakibat terhadap harga minyak bumi dunia yang semakin berfluktuasi. Prediksi harga minyak bumi yang tak menentu dalam beberapa tahun terakhir menjadi motivasi dan mendorong untuk mencari sumber energi alternatif diantaranya biomassa. Pengembangan biomassa sebagai energi alternatif yang dapat secara kontinue di produksi untuk mengatasi dan mencari solusi pengurangan konsumsi energi berbasis minyak. Upaya yang mungkin dilakukan untuk mengurangi permasalahan tersebut yaitu dengan mendorong penggunaan energi yang dapat diperbarui., dimana Indonesia akan menjadikan negara pengimpor bahan bakar minyak terbesar di dunia akibat tidak memiliki SPR (Strategic Petroleum Reserves), hal ini menunjukkan bahwa ketahanan energi nasional sebenarnya masih sangat rapuh [1]. Impor bahan bakar minyak harus dilakukan sebesar 700.000 barel perhari. Perkiraan bahwa Indonesia akan bergantung pada impor untuk memenuhi kebutuhan energi domestik sampai pada tahun 2030 menurut prediksi The Center for Energy Studies of Asia Pacific (APERC) [2]. Pusat Studi Energi Asia Pasifik (APERC) memprediksi kebutuhan energi bahan bakar akan melonjak dari angka 1.087 juta ton setara minyak pada 2002 menjadi 1.991 juta ton setara minyak pada 2030. Jika tak ada upaya yang luar biasa untuk menekan konsumsi energi berbasis minyak atau mendorong penggunaan energi terbarukan. Pemerintah telah mengeluarkan Peraturan Presiden RI No. 5 Tahun 2006 tentang Kebijakan Energi Nasional yang memuat ketentuan bahwa sumber energi alternatif tertentu adalah jenis sumber energi tertentu pengganti BBM [3]. Hal ini telah mendorong ilmuan untuk melakukan penelitian dalam mencari sumber energi alternatif sebagai pengganti energi bahan bakar fosil seperti minyak bumi dan batu bara. Limbah dan residu dari pertanian dan industri dapat digunakan sebagai sumber terbarukan alternatif untuk menghasilkan energi dan bahan baku seperti bahan kimia, selulosa, karbon dan silica [4].
Dalam Peraturan Presiden Republik Indonesia Nomor 79 Tahun 2014 Tentang Kebijakan Energi Nasional dirumuskan bahwa diperlukan peningkatan pemanfaatan sumber energi baru berbentuk padat dan sumber energi terbarukan dari jenis biomassa dan sampah [5]. Sejauh ini para ilmuan tengah burupaya memanfaatkan limbah pertanian dan limbah peternakan serta limbah industri pangan untuk menghasilkan energi alternatif yang di kenal dengan Biomassa. Biomassa merupakan bahan organik yang berasal dari tumbuh-tumbuhan yang meliputi, dedaunan, rerumputan, ranting, gulma, limbah pertanian, limbah peternakan, limbah kehutanan dan gambut yang dihasilkan melalui proses fotosintetik, baik berupa produk maupun buangan [6]. Kelebihan energi biomassa diantaranya merupakan sumber energi yang dapat diperbaharui (renewable) sehingga dapat menyediakan sumber energi secara berkesinambungan (sustainable). Sebagaimana dalam kebijakan pengembangan energi terbarukan dan konversi energi Departemen ESDM (2016) disebutkan bahwa potensi energi biomassa di Indonesia cukup besar mencapai $49.8 \mathrm{GWe}$ [7].

Pengembangan dan penggunaan biomassa ini belum dilaksanakan secara maksimal di karenakan sebahagian masyarakat belum memahami cara pemanfaatan limbah menjadi sesuatu yang lebih bermanfaat. Tebu tibarau sebagai tumbuhan yang belum termanfaatkan dijadikan kandidat bahan baku briket dalam pengembangan energi terbarukan untuk mencapai ketahanan energi nasional [8]. Tumbuhan tebu tibarau (Saccharum Spontaneum Linn) adalah tumbuhan yang hidupnya banyak di jumpai di sekitar pinggiran sungai, dan juga didataran atau dirawa-rawa [9]. Tumbuhan semak belukar di pinggiran sungai dan didataran, kebanyakan masyarakat tidak memanfaatkannya, dan hanya dibiarkan sebagai semak belukar. Pengembangan tibarau tebu yang direkomendasikan sebagai pengganti bahan bakar alternatif yang ramah lingkungan dan ekonomis dapat berupa briket sebagai bahan bakar padat.

Limbah kulit dari buah durian (Durio Zibethinus Murr) yang selama terbuang menjadi sampah sangat dimungkinkan untuk dapat dimanfaatkan. Pemanfaatan limbah kulit durian menjadi perhatian dalam pengembangan potensi bahan bakar alternatif. Tentunya proses diversifikasi produk menjadi tujuan konsepsi teknologi penerapan berupa pembuatan briket berbahan baku kulit durian.

Penelitian tentang briket dari berbagai bahan baku telah banyak dilakukan. Karakteristik nilai kalor briket tebu tibarau yang dihasilkan dari suatu 
kajian yaitu $11.221,72 \mathrm{~kJ} / \mathrm{kg}$ dengan densitas 0,565 $\mathrm{gr} / \mathrm{cm}^{3}$ pada komposisi perbandingan persentase 80 : 20 [8]. Nilai kalor briket tebu tibarau dengan menggunakan perekat inggu diperoleh sebesar $14608,36 \mathrm{~kJ} / \mathrm{Kg}$ dan densitasnya sebesar 302,98 $\mathrm{Kg} / \mathrm{m}^{3}$ [10]. Penelitian yang memanfaatkan limbah kulit durian menjadi biobriket sebagai bahan bakar alternatif terbarukan menghasilkan nilai kalor $6.274,29 \mathrm{kal} / \mathrm{g}$ dan densitas $0,99 \mathrm{~g} / \mathrm{mL}$ [11]. Lalit K Singh, et al [12] from Pelgia Research LibraryIndian Institute of Technology melaporkan bahwa tumbuhan tebu tibarau memiliki kandungan kimia. Potensi yang dimiliki tumbuhan tebu tibarau ini dapat direkomendasikan untuk bahan baku pengembangan bahan bakar nabati.

Berdasarkan wacana yang disampaikan dalam melakukan pengembangan energi bahan bakar alternatif berupa briket maka diperlukan adanya fokus kajian terhadap performanya. Kajian karakteristik nilai kalor briket campuran tebu tibarau dan kulit durian sehingga inovasi bahan bakar alternatif dapat diterapkan sebagai bentuk kontribusi dalam mencapai ketahanan energi nasional.

\section{Metode Penelitian}

Pada penelitian ini dilakukan eksperimen terhadap sampel uji briket campuran tebu tibarau dan kulit durian. Pembuatan dan pengembangan bahan bakar briket berbahan baku campuran tebu tibarau dan kulit durian (Gambar 1 dan 2). Tebu tibarau dan kulit durian sebelumnya dicacah dan digiling untuk dijadikan partikel butiran (mesh) (Gambar 3 dan 4).

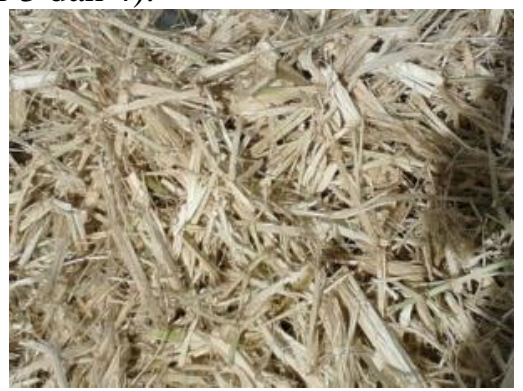

Gambar 1. Tebu Tibarau ketika dijemur

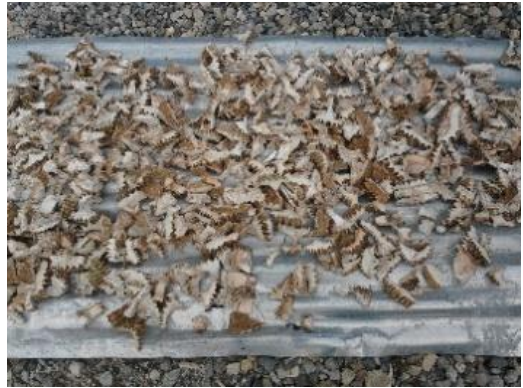

Gambar 2. Kulit Durian ketika dijemur

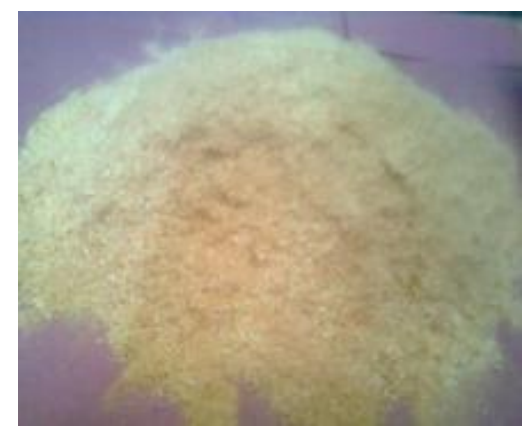

Gambar 3. Partikel Tebu Tibarau

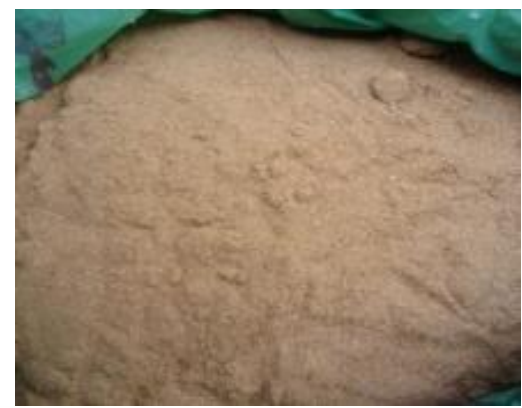

Gambar 4. Partikel Kulit Durian

Bahan perekat yang digunakan pada pembuatan briket ini yaitu tapioka, damar, dan gambir. Persentase perbandingan optimal campuran sebagai varians sebagai metode pembuatan briket. Perbandingan campuran bahan baku berupa tebu tibarau dan kulit durian dengan perekat menggunakan persentase (45\%: $45 \%: 10 \%),(40 \%$ : 40\% : 20\%), (35\%: $35 \%$ : 30\%), (30\%: $30 \%$ : $40 \%)$. Varians campuran yang telah dipersiapkan dan diaduk, kemudian dilakukan pencetakan dengan tekanan kompaksi sebesar $100 \mathrm{kgf} / \mathrm{cm}^{2}$. Briket campuran tebu tibarau dan kulit durian yang telah dicetak kemudian di dijemur pada panas matahari dalam beberapa hari. Pengukuran perbandingan massa basah dan massa kering briket yang telah dicetak dilakukan untuk mendapatkan kadar air dan densitas briket. Selanjutnya pengambilan sampel uji dari bagian briket yang sudah kering dan melakukan pengujian di laboratorium untuk mendapatkan nalai kalor briket.

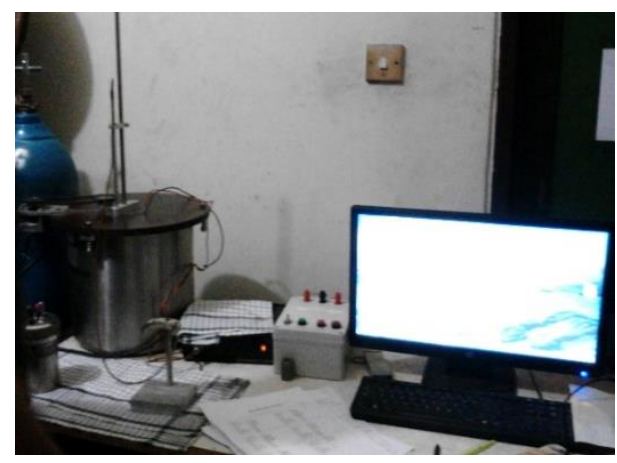

Gambar 5. Alat Bomb Calorimeter 
Pengujian di laboratorium dalam penelitian ini menggunakan alat "Bomb Calorimeter" (Gambar 5) sesuai standar uji ASTM D-2015. Dalam pelaksasnaan penelitian ini pengkondisian suhu ruangan yang stabil sangat dibutuhkan untuk mendapatkan data uji yang valid. Dari pengujian ini diperoleh karakteristik yang berhubungan dengan energi panas pembakaran atau nilai kalor (calorific value).

Analisis dari tiap jenis briket campuran tebu tibarau dan kulit durian dengan komposisi persentase antara bahan bahan baku dan perekat serta parameter perlakuan akan di catat dan ditabulasikan pada tabel pendataan yang dirancang sesuai kebutuhan. Analisis data dan perhitungan menggunakan persamaan baku yang ada dan dilakukan pengolahan data dengan berbantuan komputasi. Nilai kalor tertinggi $\left(\mathrm{N}_{\mathrm{bb}}\right)$ dapat dihitung dengan menggunakan persamaan:

$$
N_{b b}=\frac{\left(t_{2}-t_{1}\right) c_{v}}{m_{b b}}(\mathrm{~kJ} / \mathrm{Kg})
$$

dimana:

$$
\begin{aligned}
& \mathrm{N}_{\mathrm{bb}}=\text { Nilai kalor briket } \\
& \mathrm{t}_{2}=\text { Temperatur Akhir }\left({ }^{\circ} \mathrm{C}\right) \\
& \mathrm{t}_{1} \quad=\text { Temperatur Awal }\left({ }^{\circ} \mathrm{C}\right) \\
& \mathrm{c}_{\mathrm{v}}=\text { Panas Jenis Alat }(\text { bomb Calorimeter }) \\
& \mathrm{m}_{\mathrm{bb}}=\text { Massa briket yang di uji }
\end{aligned}
$$

\section{HASIL DAN PEMBAHASAN}

Persiapan bahan baku pada penelitian ini dilakukan sebanyak mungkin untuk pembuatan dan pencetakan briket campuran tebu tibarau dan kulit durian. Kebutuhan bahan baku penelitian berupa tebu tibarau dan kulit durian dengan memprediksi terhadap banyaknya jumlah variasi campuran antara bahan baku dengan perekat. Hal ini dilaksanakan berdasarkan alur pemikiran sesuai teknis pembuatan briket maka diperoleh beberapa protototype model fisis hasil pengembangan pembuatan (Gambar 6).

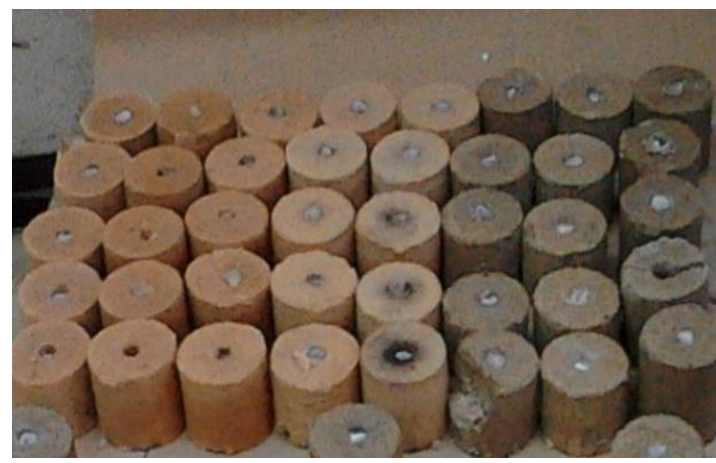

Gambar 6. Briket Campuran Tebu Tibarau dan Kulit Durian

Berdasarkan tatanan prosedur penggunaan alat Bomb Calorimeter tersebut maka diperoleh nilai kalor untuk masing-masing briket campuran tebu tibarau dan kulit durian dengan perekat yang berbeda. Besaran nilai yang diperoleh sejumlah besaran fisika pada Tabel 1 s.d. 3 diturunkan berdasarkan formula yang baku dengan memasukkan data-data dari hasil pengukuran pada peralatan uji Bomb Calorimeter.

Dari hasil uji karakteristik nilai kalor briket campuran tebu tibarau dan kulit durian terhadap semua variasi dengan perekat yang berbeda diperoleh perbedaan yang signifikan. Dari semua perekat yang digunakan pada pembuatan briket campuran tebu tibarau dan kulit durian menunjukkan karakteristik yang berbeda-beda.

Tabel 1. Karakteristik Briket Campuran Tebu Tibarau dan Kulit Durian dengan Perekat Tapioka

\begin{tabular}{cccccc}
\hline \multicolumn{2}{c}{ Komposisi Persentase } & $\begin{array}{c}\text { Massa } \\
\text { Kering } \\
\text { Briket } \\
(\mathbf{m})\end{array}$ & $\begin{array}{c}\text { Massa } \\
\text { Jenis } \\
(\boldsymbol{\rho})\end{array}$ & $\begin{array}{c}\text { Nilai Kalor } \\
(\mathbf{C V}) \\
\boldsymbol{n}_{\boldsymbol{B} \boldsymbol{B}}\end{array}$ \\
\hline $\begin{array}{c}\text { Tebu } \\
\text { Tibarau } \\
(\%)\end{array}$ & $\begin{array}{c}\text { Kulit } \\
\text { Durian } \\
(\%)\end{array}$ & $\begin{array}{c}\text { Tapioka } \\
(\%)\end{array}$ & $(\mathrm{gr})$ & $\left(\mathrm{kg} / \mathrm{m}^{3}\right)$ & $(\mathbf{k J} / \mathbf{k g})$ \\
\hline 45 & 45 & 10 & 25,4 & 407,41 & 9591,19 \\
\hline 40 & 40 & 20 & 28,4 & 455,53 & 11416,04 \\
\hline 35 & 35 & 30 & 27,6 & 442,70 & 10222,05 \\
\hline 30 & 30 & 40 & 25 & 400,99 & 8882,99 \\
\hline
\end{tabular}


Tabel 2. Karakteristik Briket Campuran Tebu Tibarau dan Kulit Durian dengan Perekat Damar

\begin{tabular}{cccccc}
\hline \multicolumn{2}{c}{ Komposisi Persentase } & $\begin{array}{c}\text { Massa } \\
\text { Kering } \\
\text { Briket } \\
(\mathbf{m})\end{array}$ & $\begin{array}{c}\text { Massa } \\
\text { Jenis } \\
(\boldsymbol{\rho})\end{array}$ & $\begin{array}{c}\text { Nilai Kalor } \\
(\mathbf{C V}) \\
\boldsymbol{n}_{\boldsymbol{B} \boldsymbol{B}}\end{array}$ \\
\hline $\begin{array}{c}\text { Tebu } \\
\text { Tibarau } \\
(\%)\end{array}$ & $\begin{array}{c}\text { Kulit } \\
\text { Durian } \\
(\%)\end{array}$ & $\begin{array}{c}\text { Damar } \\
(\%)\end{array}$ & $(\mathrm{gr})$ & $\left(\mathrm{kg} / \mathrm{m}^{3}\right)$ & $(\mathbf{k J} / \mathbf{k g})$ \\
\hline 45 & 45 & 10 & 20,8 & 407,77 & 15265,78 \\
\hline 40 & 40 & 20 & 20,6 & 494,03 & 15692,83 \\
\hline 35 & 35 & 30 & 22,2 & 435,21 & 14920,66 \\
\hline 30 & 30 & 40 & 25,2 & 403,85 & 14191,97 \\
\hline
\end{tabular}

Tabel 3. Karakteristik Briket Campuran Tebu Tibarau dan Kulit Durian dengan Perekat Gambir

\begin{tabular}{cccccc}
\hline \multicolumn{2}{c}{ Komposisi Persentase } & $\begin{array}{c}\text { Massa } \\
\text { Kering } \\
\text { Briket } \\
(\mathbf{m})\end{array}$ & $\begin{array}{c}\text { Massa } \\
\text { Jenis } \\
(\boldsymbol{\rho})\end{array}$ & $\begin{array}{c}\text { Nilai Kalor } \\
(\mathbf{C V}) \\
\boldsymbol{n}_{\boldsymbol{B} \boldsymbol{B}}\end{array}$ \\
\hline $\begin{array}{c}\text { Tebu } \\
\text { Tibarau } \\
(\%)\end{array}$ & $\begin{array}{c}\text { Kulit } \\
\text { Durian } \\
(\%)\end{array}$ & $\begin{array}{c}\text { Gambir } \\
(\%)\end{array}$ & $(\mathrm{gr})$ & $\left(\mathrm{kg} / \mathrm{m}^{3}\right)$ & $(\mathbf{k J} / \mathbf{k g})$ \\
\hline 45 & 45 & 10 & 28,2 & 552,84 & 14873,29 \\
\hline 40 & 40 & 20 & 27,4 & 682,23 & 16967,91 \\
\hline 35 & 35 & 30 & 24,8 & 486,19 & 16248,37 \\
\hline 30 & 30 & 40 & 34,8 & 537,16 & 16589,73 \\
\hline
\end{tabular}

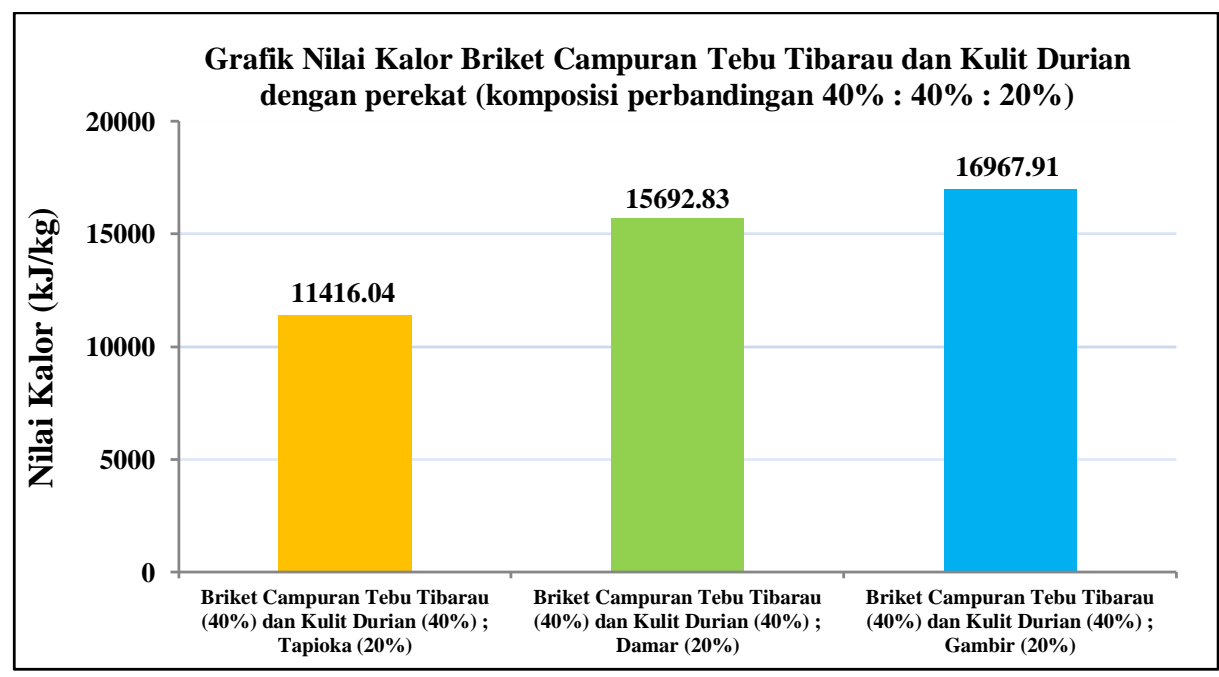

Gambar 7. Grafik Nilai Kalor Briket Campuran Tebu Tibarau dan Kulit Durian dengan Perekat (komposisi perbandingan 40\%: 40\%: 20\%) 


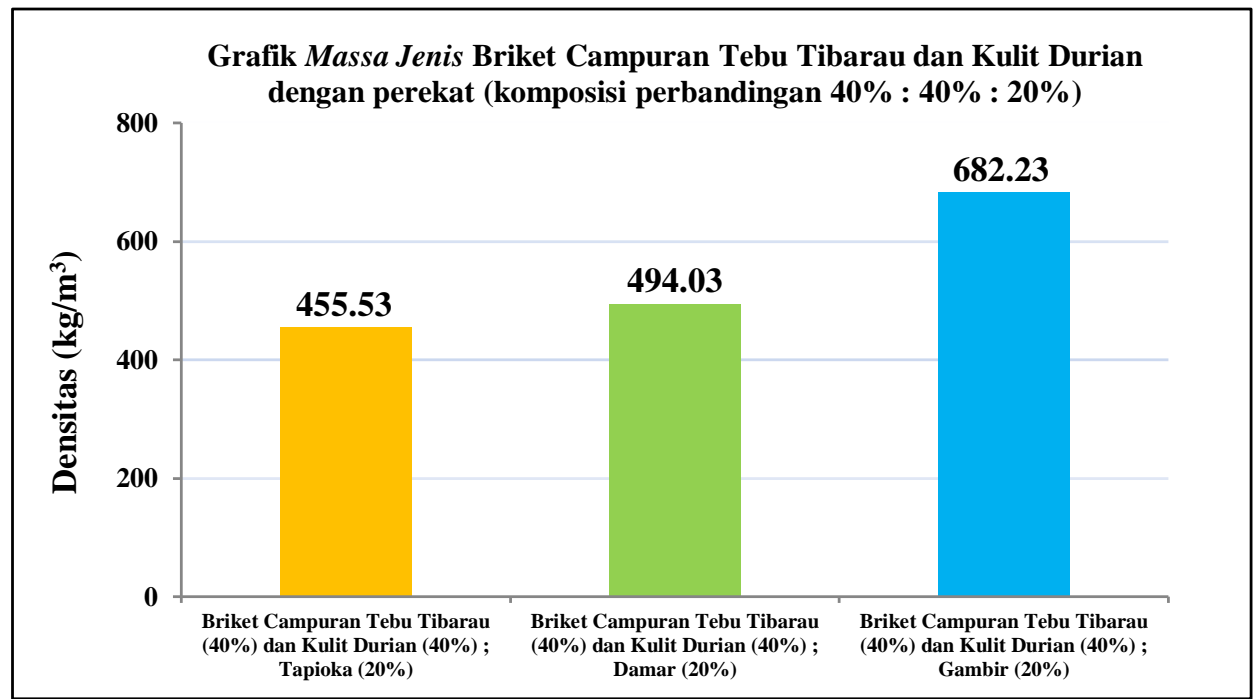

Gambar 8. Grafik Massa Jenis Briket Campuran Tebu Tibarau dan Kulit Durian dengan Perekat (komposisi perbandingan 40\%: 40\%: 20\%)

Briket campuran tebu tibarau dan kulit durian dengan perekat tapioka diperoleh nilai kalor maksimal sebesar $11416,04 \mathrm{~kJ} / \mathrm{Kg}$ dan massa jenis (densitas) $455,53 \mathrm{Kg} / \mathrm{m}^{3}$. Kondisi ini berada pada komposisi perbandingan campuran $40 \%$ : $40 \%$ : 20\%. Secara tabulasi dapat dilihat pada Tabel 1. Sedangkan briket campuran tebu tibarau dan kulit durian dengan perekat damar diperoleh nilai kalor maksimal sebesar 15692,83 kJ/Kg dan massa jenis $494,03 \mathrm{Kg} / \mathrm{m}^{3}$. Kondisi ini juga berada pada komposisi perbandingan campuran 40\%: $40 \%$ : 20\%. Secara tabulasi dapat dilihat pada Tabel 2. Demikian juga pada briket campuran tebu tibarau dan kulit durian dengan perekat gambir diperoleh nilai kalor maksimal sebesar 16967,91 kJ/Kg dan massa jenis $682,23 \mathrm{Kg} / \mathrm{m}^{3}$. Kondisi ini juga berada pada komposisi perbandingan campuran $40 \%$ : $40 \%$ : $20 \%$. Secara tabulasi dapat dilihat pada Tabel 3.

Parameter kualitas penting pada suatu briket sebagai bahan bakar padat adalah nilai kalor. Sehingga kualitas briket akan semakin baik bila nilai kalor yang dihasilkan semakin tinggi. Pencapaian nilai kalor yang maksimal sangat diperlukan dalam menganalisis kualitas briket untuk perbandingan yang optimal. Bila diperhatikan untuk semua briket yang dihasilkan dengan perekat yang berbeda maka pada perbandingan komposisi campuran 40\%: 40\% : $20 \%$ diperoleh nilai kalor yang maksimal. Dengan demikian pada komposisi campuran yang optimal ini diperoleh nilai kalor yang maksimal sehingga hal ini dapat direkomendasi untuk pembuatan briket (Gambar 7). Selain itu densitas briket pada komposisi campuran tersebut memiliki nilai yang tertinggi juga (Gambar 8). Dari kondisi ini dapat disampaikan bahwa semakin massa jenis briket semakin tinggi pula nilai kalor yang diperolehnya. Semakin besar nilai kalor maka kecepatan pembakaran semakin lambat. Briket (biomassa) yang memiliki massa jenis (densitas) yang tinggi memiliki nilai kalor yang tinggi pula, dan jika biomassa tersebut mengalami proses pembakaran, kecepatan pembakarannya lebih lambat dibandingkan dengan biomassa yang memiliki berat jenis yang lebih rendah.

Parameter nilai kalor sebagai karakteristik yang dibutuhkan sesuai dengan keberadaannya pada setiap jenis bahan bakar. Bahan bakar briket yang merupakan bahan bakar padat yang dihasilkan dengan metode proses pencampuran dengan kompaksi (the method of mixing with compacting). Briket dengan perpaduan butiran partikel sehingga menjadi solid diberikan perekat (adhesive). Adanya konsentrasi penggunaan perekat pada pembuatan briket, memiliki pengaruh terhadap nilai kalor yang dihasilkannya. Penelitian ini menunjukkan bahwa konsentrasi perekat sebesar $20 \%$ untuk setiap jenis perekat diperoleh nilai kalor yang maksimum pula. Hal ini sesuai dengan pernyataan bahwa Penggunaan jenis perekat dan konsentrasinya pada pembuatan briket merupakan salah satu faktor penting dalam pembuatan briket [13]. Pada penelitian ini, penggunaan jenis perekat gambir pada briket campuran tebu tibarau dan kulit durian menunjukkan kualitas briket yang baik dibandingkan dengan perekat yang lain. Hal ini dikarekan bahwa masing-masing jenis perekat memiliki kandungan unsur $\mathrm{C}$ (karbon) yang berbeda. Bahan perekat memiliki sifat dapat 
meningkatkan nilai kalor karena mengandung unsur C [14]. Sehingga dari ketiga jenis perekat yang digunakan pada pembuatan briket campuran tebu tibarau dan kulit durian memiliki karakteristik yang spesifik dan ciri khas tersendiri. Namun dalam penggunaan sebagai bagian dari pengembangan dalam menghasilkan briket lainnya disesuaikan dengan kebutuhan, kemudahan, ekonomi dan ketersediaannya.

Dari hasil penelitian ini dan data analisisnya dapat dinyatakan bahwa komposisi yang memiliki nilai kalor tertinggi direkomendasikan untuk dapat dikembangkan sebagai bahan bakar energi alternatif. Namun perlu diperhatikan juga bahwa perekat yang umum dan mudah diperoleh menjadi prioritas utama digunakan dalam membuat briket.

\section{KESIMPULAN}

Dari penelitian ini dapat disimpulkan bahwa pemanfaatan limbah tumbuhan tebu tibarau dan kulit durian berpotensi sebagai kandidat bahan baku briket. Dalam pengembangan energi terbarukan berupa bahn bakar briket dapat dilakukan untuk mencapai ketahanan energi nasional. Karakteristik nilai kalor briket campuran tebu tibarau dan kulit durian diperoleh nilai kalor yang tertinggi menggunakan perekat gambir yaitu $16967,91 \mathrm{~kJ} / \mathrm{Kg}$ dan massa jenis $682,23 \mathrm{Kg} / \mathrm{m}^{3}$. Briket yang memiliki massa jenis (densitas) yang tinggi memiliki nilai kalor yang tinggi pula. Perbandingan konsentrasi komposisi campuran pada pembuatan briket ini yaitu $40 \%: 40 \%: 20 \%$. Pada pembuatan briket, konsentrasi penggunaan perekat berpengaruh terhadap nilai kalor yang dihasilkannya. Selain itu, besaran butir (mesh), gaya penekanan (kompaksi) juga mempengaruhi karakteristik nilai kalor dan massa jenis briket tersebut.

\section{DAFTAR PUSTAKa}

[1] Pri Agung Rakhmanto, Ketahanan Energi Nasional Masih Rapuh, dalam Koran Kompas, (2013); Terbit Edisi Jumat 29 Nopembert 2013

[2] http://edukasi.kompas.com/

[3] Peraturan Presiden Republik Indonesia Nomor 5 Tahun 2006 Tentang Kebijakan Energi Nasional yang memuat ketentuan bahwa sumber energi alternatif tertentu adalah jenis sumber energi tertentu pengganti Bahan Bakar Minyak

[4] Tyagi, V. K., \& Lo, S. L. (2013). Sludge: a waste or renewable source for energy and resources recovery?. Renewable and Sustainable Energy Reviews, 25, 708-728.
[5] Peraturan Pemerintah Nomor 79 Tahun 2014 Tentang Kebijakan Energi Nasional

[6] Borman, G. L., \& Ragland, K. W. Combustion engineering, 1998.

[7] Departemen Energi dan Sumberdaya Mineral (2016); Statistik Energi Indonesia

[8] Nurdin, H., Hasanuddin, H., Darmawi, D., \& Prasetya, F. (2018, April). Analysis of Calorific Value of Tibarau Cane Briquette. In IOP Conference Series: Materials Science and Engineering (Vol. 335, No. 1, p. 012058). IOP Publishing.

[9] Hasanuddin, H., Nurdin, H., \& Putra, R. A. (2016). Tebu Tibarau: Tumbuhan Energi Terlupakan (Mengolah Potensi untuk Energi Tembakau).

[10] Nurdin, H., Hasanuddin, H., \& Darmawi, D. (2018). Karakteristik Nilai Kalor Briket Tebu Tibarau Sebagai Bahan Bakar Alternatif. INVOTEK: Jurnal Inovasi Vokasional dan Teknologi, 18(1), 19-24.

[11] Nuriana, W., \& Anisa, N. (2013). Karakteristik Biobriket Kulit Durian Sebagai Bahan Bakar Alternatif Terbarukan. Journal of Agroindustrial Technology, 23(1).

[12] Singh, L. K., Chaudhary, G., Majumder, C., \& Ghosh, S. (2011). Utilization of hemicellulosic fraction of lignocellulosic biomaterial for bioethanol production. Advances in Applied Science Research, 2(5), 508-521.

[13] Akintunde, M. A., \& Seriki, M. E. (2013). Effect of paper paste on the calorific value of sawdust briquette. International Journal of Advancements in Research \& Technology, 2(1).

[14] Manik, F. S. (2010). Pemanfaatan spent bleaching earth dari proses pemucatan cpo sebagai bahan baku briket. Bogor: Institut Pertanian Bogor.

\section{UCAPAN TERIMA KASIH}

Pelaksana Penelitian ini mengucapkan terima kasih kepada Rektor Universitas Negeri Padang yang telah membiayai Penelitian ini melalui dana PNBP Tahun Anggaran 2018.

\section{Biodata Penulis}

Hendri Nurdin lahir di Medan 28 Februari 1973 menamatkan pendidikan Sarjana pada bidang Ilmu Teknik Mesin di Medan. Kemudian melanjutkan studi dan memperoleh Magister Teknik di bidang Material \& Struktur (2006) di USU Medan. Sampai saat ini, merupakan staf pengajar di FT-UNP Jurusan Teknik Mesin. Pengalaman mengajar selama ini dalam mata kuliah Teknologi Bahan, Pengujian Bahan, Elemen Mesin, Mesin Teknologi Terapan, Fisika Teknik. Pengembangan bidang 
ilmu dilakukan melalui penelitian dengan fokus natural science materials. Pengembangan lanjutan diarahkan bernuansa penelitian bidang renewable energy \& natural science.

Hasanuddin lahir di Inuman - Indragiri, 20 Mei 1955, di FPTK IKIP Padang pada bidang Pendidikan Teknik Mesin. Kemudian melanjutkan studi di IPB Bogor dan memperoleh Magister Science di bidang Ilmu Perencanaan Pembangunan Wilayah \& Pedesaan (1993). Sampai saat ini, merupakan staf pengajar di FT-UNP Jurusan Teknik Mesin. Pengalaman mengajar selama ini dalam mata kuliah Mekanika Fluida, Mesin Teknologi Terapan, Manajemen Industri, Manajemen Operasi/Produksi, Kewirausahaan, Evaluasi Proyek. Pengembangan bidang ilmu dilakukan melalui penelitian dengan fokus konversi energi \& renewable (Kincir Angin) .

Waskito lahir di Medan, 08 Agustus 1961, menamatkan pendidikan Sarjana di FPTK IKIP Padang pada bidang Pendidikan Teknik Mesin Tahun 1985. Kemudian melanjutkan studi di ITB Bandung dan memperoleh Magister Teknik di bidang Konstruksi Mesin (1997). Kemudian menamatkan Doktor di bidang Ilmu Pendidikan di UNP Padang Tahun 2011. Sampai saat ini, merupakan staf pengajar di FT-UNP Jurusan Teknik Mesin. Pengalaman mengajar selama ini dalam mata kuliah Rancangan Konstruksi Mesin, Gambar Mesin. Pengembangan bidang ilmu dilakukan melalui penelitian dengan fokus Ilmu kependidikan.

Darmawi lahir di Padang, 05 Maret 1954, menamatkan pendidikan Sarjana di FPTK IKIP Padang pada bidang Pendidikan Teknik Mesin. Kemudian melanjutkan studi di IKIP Jakarta dan memperoleh Magister Pendidikan di bidang Pendidikan Teknologi dan Kejuruan (1995). Sampai saat ini, merupakan staf pengajar di FTUNP Jurusan Teknik Mesin. Pengalaman mengajar selama ini dalam mata kuliah Statika Struktur, Mekanika Kekuatan Bahan, Matematika Teknik, Metode Mengajar Khusus, Fenomena Dasar Mesin. 